\title{
TOURIST MOTIVES FOR VISITING VITOVNICA MONASTERY
}

\author{
Aleksandar Antić, Violeta Vojkan ${ }^{1}$ \\ Received: April 23, 2018 | Accepted: October 12, 2018
}

\begin{abstract}
Summary: The Monastery Vitovnica is an Orthodox monastery founded in 1291, when King Stefan Uroš IIIMilutin defeated the Bulgarian enemies who ruled Braničevo from the town of Ždrelo in Gornjačka gorge. Today the monastery is a cultural and historical monument of great importance for the Braničevo district and Serbia. The research included a survey of tourists about the motive of visiting Vitovnica monastery. The respondents rated the offered motifs on the scale from 1 to 5 . The objective of the paper is to assess the most common motives and to examine the attitudes of tourists, local residents and tourist workers regarding the cultural offer of the monastery. The motives of tradition and customs were shown to be the highest grade, while the lowest grade assessed scientificeducational motives. The results of the SWOT analysis showed that the monastery possesses exceptional tourist potentials when it comes to its natural environment and an anthropogenic basis for the development of tourism. An empirical survey conducted on a sample of 85 respondents aimed to show the specific views and motives of tourists when visiting the monastery. The data obtained in the research were processed using the statistical program SPSS (version 17.0).
\end{abstract}

Key words: tourist motives, religious tourism, cultural tourism, Vitovnica Monastery.

\section{INTRODUCTION}

Many tourist destinations are positioned and placed on the market as cultural, but little is known about the motives that trigger cultural tourism movements. Existing explorations of cultural tourists mainly focused on the identification of cultural tourists when visiting a cultural object (museums, galleries, theaters, religious monuments of culture, etc.) and understanding their motivations in a situation context. It should be noted that there is a lack of cross-cultural research on the attitudes and motivation of tourists despite the multicultural nature of international tourism (Reisinger, 2005). A religious or spiritually motivated journey has become a widespread and popular tourist activity in recent decades. An important segment of international tourism is occu-

\footnotetext{
University of Novi Sad, Faculty of Natural Sciences and Mathematics, Department of Geography, Tourism and Hotel Management, Email: a.antic994@gmai.com
} 
pied, which has increased significantly in recent years in both proportional and absolute terms. Continuous growth in this segment of the tourism market suggests a rising trend in the future (Bywater, 1994).

The needs of tourists are always a good starting point for discussion about the motivation for different ways of experiencing tourism. The diversity of tourist needs has led to the emergence of various forms of tourism, such as: cultural tourism, religious tourism, geotourism, and others. The aspect that launches the whole process of determining tourist needs is the decision of the individual (Ambrož and Ovsenik, 2011). The task of the tourism industry is to recognize the tourist needs and to make a quality offer, which due to adequate promotion will be successfully implemented on the tourist market. Therefore, tourists' motives allow tourism workers to recognize their needs and satisfy them as much as possible. Dalen (2006) argued that religion and spirituality continue to be the most frequent travel motives. Many great tourist destinations have developed largely in line with their connections to holy people, places and events.

In order to determine the significance of tourist motives based on spirituality, religious architecture, traditional and cultural identity and other values, we need an analysis at the local level. For the purpose of this study, the Monastery Vitovnica was isolated as a monument of culture and spirituality of exceptional significance. The cultural and historical identity of the monastery has impressive tourist potentials that can significantly contribute to the development of tourism throughout Braničevo district. Historically, this monastery symbolically represents the final coupling of the defensive region of Serbia and, as such, plays an important role in the representativeness of the history of this region.

The subject of the work is the attitudes and motives of tourists when visiting the monastery Vitovnica. The study included the survey conducted with the topic "Research on attitudes and motives for visiting the Vitovnica Monastery". The aim of the paper is to assess the most common motives and to examine the views of tourists, local residents and tourist workers regarding the tourist offer of the monastery.

\section{HISTORY OF THE MONASTERY}

There are no reliable data on the time of the construction of the monastery, because there is a missing founding charter, an inscription or a founders' composition. Undoubtedly, this is after the Church of Trša, the oldest church in the Braničevo Diocese. The bilingual inscription (Old Serbian and Armenian) on a stone embedded in the northern wall of the folded part of the church, speaks of the church of the Holy Apostles Peter and James, which was built by Babug's son, Vlado in 1218. A later tradition, both in the monastery and in the surrounding villages, connect Vitovnica with the Serbian king Milutin, who ultimately took these territories to Serbia. It is possible that this great dignitary renewed the old church, or simply ordered that it be renewed, because in one human record it says: "created by the well-being of the blessed King of the Kingdom of Serbia, Milutin". Mihailo Riznić, in the "Starinar"science magazine of the Serbian Archeology Society, published in 1888, writes: "King Milutin could raise this monastery after the Tartars in 1291. Then they stood up against the northern Serbian king Dragutin, Milu- 
tin's brother, two rebels in Ždrelo, Drman and Kudelin. Milutin gathered a strong army and greatly defeated the Tatars so the Mlava has gone bloody" (Dragović, 1933). Knowing the founders' activity of King Milutin Nemanjić, it is very possible that he raised the monastery and was later itsfounder. The battle with the Tatars came at an inconvenient time for Milutin because in his plans there was a great deal of struggle with his southern neighbor Byzantium, so the expression of gratitude for the victory was obvious.

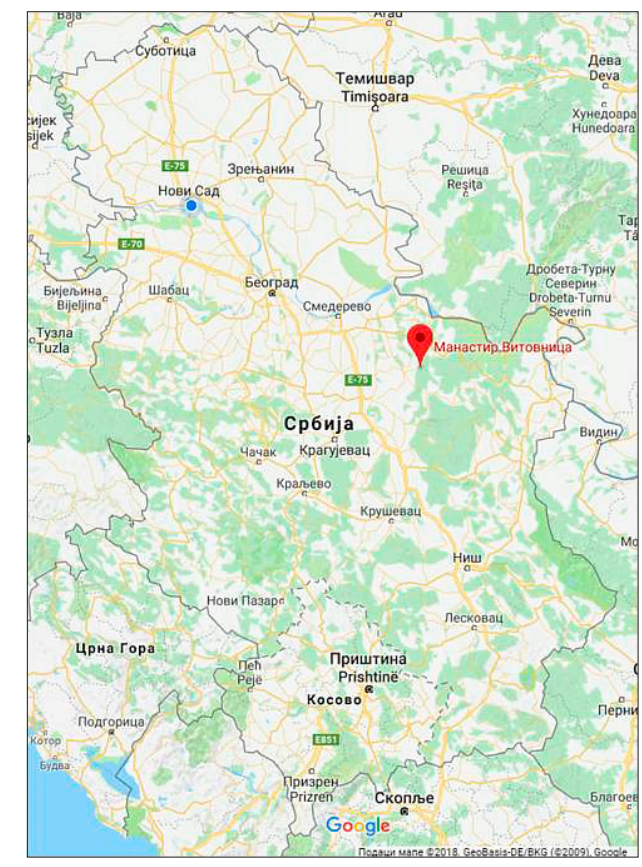

Map 1. Geographical position of Vitovnica Monastery Source: Google maps

For the entire duration of the Serbian medieval state there are no data on this monastery. It is mentioned only by Turkish lists. The census of 1537 says that there are two monks living in the Prečiste Monastery near the Vitovnica River, and the obligations of the monastery towards the Sultan's box are 400 acres. Undoubtedly, the monastery was in a material state of good standing, because in 1557, at the time of the Igman Macarius, the famous goldsmith Vuk Kondo chained the golden viticultural gospel. We can trace the history of the monastery throughout the 17th century through the records on the monastery books. Migration at the end of the XVI century under Arseny III, and in the next century under Arseny IV, blew out viticultural books on various sides: a psalter from 1661 is located in the National Library, one book from 1619 in Kiev, one in the patriarchal library in Sremski Karlovci, a book from 1628 in the Pakri Monastery, etc. During the migration the seal of viticulture Igman Visarion from 1703, came to the Krušedol Monastery, and a silver cup - the work of the Luke, the silversmith from Ćiprovac from 1662 - is located in Bešenovo. There is also the aforementioned, goldenbound gospel from 1557 (Mitošević, 1979). 
During the Austrian occupation of northern Serbia (1718-1739), Egzarh Maksim (Ratković) visited Vitovnica and left a description of the monastery where only two monks have been living with the prior. At the time of the Kočin krajina, the monastery was ruined by the Turks. Then it was fired and the cells were pulled down to the ground. The monastery was so neglected that the village cattle lived in it. Ever since the time, Karadjordje's monks and peasants started to gradually restore it. The first reconstruction of the monastery was performed by Ilija Dobrilović. The following reconstruction is performed by Paulj Matejić from Melnica, Commander Petar Dobrnjac and Stevan Dobrnjac, Moravian prince from the period 1815-1821 with headquarters in Požarevac, who on the old foundations renewed the konak(private home) with two rooms and a kitchen. Real reconstruction was done only at the time of Prince Miloš, and at the end of his first government. From 1837, when some buildings were erected, the resurrection and the rise of Vitovnica began, in 1856, the monastery was completely restored. At that time, the church was reconstructed, annexed with a belfry, placed beneath the marble, and the whole church was covered with "white"galvanized sheet. All the surfaces are painted in the church itself. After the war, many monastic properties, cafes, shops and others were nationalized. Only the agrarian maximum has been left. In addition to nationalization, various other damage was done, a lot of construction materials saved for raising new buildings were taken, etc. (Stojanović, 1926).

\section{METHODOLOGY}

The methodology of the research was reflected in a combination of quantitative methods (statistics and Internet analysis) and qualitative methods (written documents). At the stage of defining the theoretical framework of work, bibliographic-speculative was used, and in the processing and interpretation of the results a descriptive method. In order to obtain the best possible results, the analysis of the advantages and disadvantages, benefits and disadvantages (SWOT analysis), the current tourist offer of the monastery was also made. All the respondents who participated in the survey visited Vitovnica Monastery one or more times. Of the independent variables, respondents were asked to indicate their gender, age structure, occupation, place and living conditions, level of education and family status. As far as the dependent variables are concerned, the attitudes and motives of the respondents during the visit of the monastery varied. The basis of which was the main hypothesis $\mathrm{H}$, that there are motives that are more or less represented by tourists during the visit of the monastery Vitovnica.

\section{SOCIAL AND DEMOGRAPHIC PROFILE OF THE RESPONDENTS}

The survey included 85 respondents of different sexes. As shown in Table 1, 36 men (42.4\%) and 49 women (57.6\%) participated in the study. When it comes to family status, most respondents are unmarried. It is noted that the largest percentage of respondents are between 16 and 25 years of age. In addition to these respondents, there are those 
who are between 26 and 35 years old. As for the profession, 50 respondents stated that they were employed. Also, 24 are students, 10 unemployed persons and one senior citizen participated in the survey. Most respondents have secondary education and higher education. The majority live in urban residential buildings and rural households. There are 50 people who live in the city and 35 who live in the rural area.

It can be concluded that the survey was mainly attended by the younger population living in cities and countryside. Given that cultural heritage is part of the tradition of one nation and that we leave this tradition to future generations, it is important to note that it is of utmost importance that the majority of the young population is present in this research.

Table 1. Social and demographic profile of the respondents

\begin{tabular}{|c|c|c|}
\hline & Number of respondents & Percentage \\
\hline \multicolumn{3}{|l|}{ Sex } \\
\hline Male & 36 & $42,4 \%$ \\
\hline Female & 49 & $57,6 \%$ \\
\hline Total & 85 & $100,0 \%$ \\
\hline \multicolumn{3}{|l|}{ Family status } \\
\hline Married & 45 & $52,9 \%$ \\
\hline Single & 35 & $40,1 \%$ \\
\hline Divorced & 4 & $4,7 \%$ \\
\hline Widowed & 1 & $1,2 \%$ \\
\hline \multicolumn{3}{|l|}{ Age } \\
\hline 15 or less & 0 & $0,00 \%$ \\
\hline from 16 to 25 & 35 & $41,2 \%$ \\
\hline from 26 to 35 & 33 & $33,8 \%$ \\
\hline from 36 to 45 & 10 & $11,8 \%$ \\
\hline from 46 to 55 & 6 & $7,1 \%$ \\
\hline over 55 & 1 & $1,2 \%$ \\
\hline \multicolumn{3}{|l|}{ Location } \\
\hline City-apartment & 45 & $52,9 \%$ \\
\hline City-house & 5 & $5,9 \%$ \\
\hline Countryside-apartment & 1 & $1,2 \%$ \\
\hline Countryside-house & 34 & $40 \%$ \\
\hline \multicolumn{3}{|l|}{ Occupation } \\
\hline Employed & 50 & $58,8 \%$ \\
\hline Unemployed & 10 & $11,8 \%$ \\
\hline Student (Elementary and High school) & 0 & $0,00 \%$ \\
\hline Student (University) & 24 & $28,2 \%$ \\
\hline Senior & 1 & $1,2 \%$ \\
\hline
\end{tabular}




\begin{tabular}{|c|c|c|}
\hline & Number of respondents & Percentage \\
\hline \multicolumn{3}{|l|}{ Education } \\
\hline Elementary school & 7 & $8,2 \%$ \\
\hline High school & 26 & $30,6 \%$ \\
\hline Higher education & 18 & $21,2 \%$ \\
\hline University education & 31 & $36,5 \%$ \\
\hline Master's degree and PhD & 3 & $3,5 \%$ \\
\hline
\end{tabular}

\section{INSTRUMENTS AND THE PROCESS OF SURVEYING}

The survey questionnaire on the topic "Research on attitudes and motives for visiting Vitovnica monastery" was conducted in March and April of 2018. Apart from the inhabitants and tourist workers of the municipality of Petrovac on the Mlava riverand its surroundings, respondents from Belgrade and Novi Sad also took part in the survey. The condition for completing the survey was that the respondents in the past had visited the Monastery at least once. The total number of questions in the survey was 11 . The structure of the questionnaire consisted of six socio-demographic issues (independent variables) concerning gender, family status, age, place and living conditions, occupations and levels of education, while the remaining five the questions concerned the interest in different tourist motives (dependent variables). The administration of the questionnaire was conducted as a self-administration, which means that respondents were sent a questionnaire via the Internet to answer questions independently.

The form of the questionnaire is a scale of estimates, ranging from 1 to 5 , more precisely, from a lack of interest-1, little interest-2, intermediate interest-3, higher interest- 4 to a high level of interest-5.

\section{RESULTS AND DISCUSSION}

The tourist motives analysed in this paper are directly related to the Monastery of Vitovnica. The purpose was to present the motives of the visitors towards the monastery, in order to determine the most common motives that drive tourists when visiting this cultural property. Respondents were asked questions regarding the following subjects:

1. cultural-historical motives;

2. spiritual motives;

3. artistic motives;

4. motifs of tradition and customs; and

5. scientific-educational motives.

The cultural significance of tourism, as a phenomenon characterized by a high degree of communication between individuals, is extremely high. It could be said that al- 
most every tourist form contains elements of cultural activity. Tourism is an important channel for the exchange of cultures and an effective means of understanding among civilizations. Given the diversity of cultural forms that are of interest to the modern tourist, cultural tourism is one of the most important forms of tourism. According to WTO estimates, in the publication "Tourism: 2020 Vision", the cultural tourism market is predicted to be one of the five leading segments of the tourism market in the future (Hadžić, 2004).

As far as cultural and historical motives are concerned, the results are quite high. A significant number of respondents who have marked these motives with a score of 5 are noticed. None of the participants assessed with grade 1, and with a score of 2 only three respondents.

The cultural aspect of the Monastery is the widest concept. Culture of the Monastery, in addition to certain material values, also implies monastic attitude towards visitors, ambience in the monastery complex and other non-material values, which can be of crucial importance for the development of tourism of the Monastery.Positive assessment of cultural and historical motives is expected, since the monastery originates from the 13th century and symbolizes the cultural and historical identity of Braničevo.

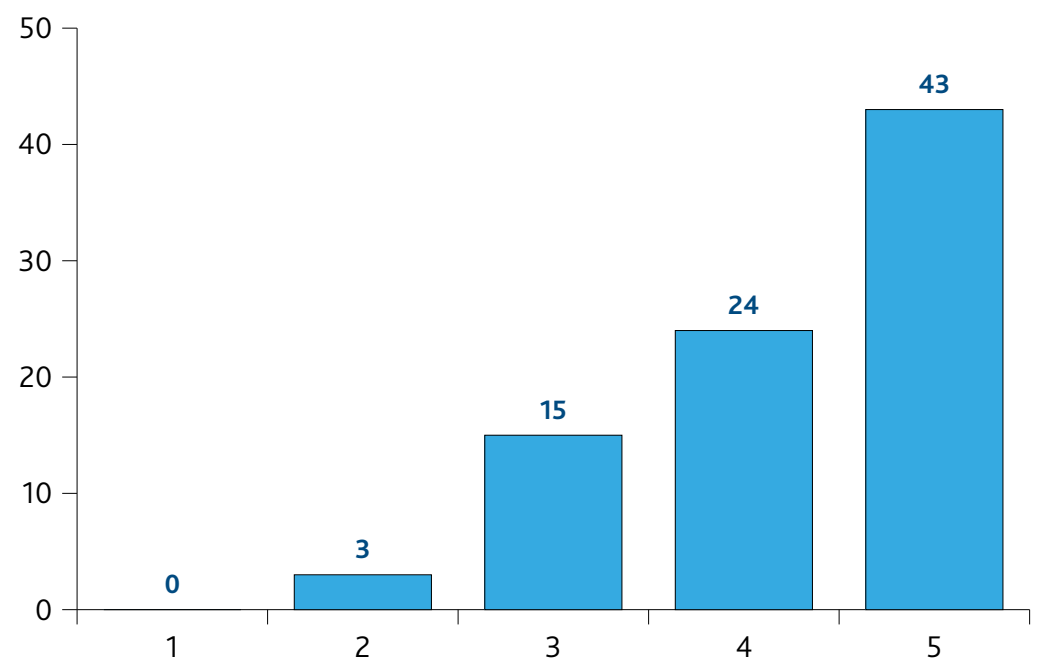

Chart 1. Evaluation of cultural and historical motives (number od respondents)

Travel inspired by spiritual motives is not a new phenomenon. Religion has long been an integral motive for travel and is usually considered to be the oldest form of noneconomic travel (Jackovski and Smith 1992). Every year, millions of people travel to the main destinations of pilgrimage, of ancient and modern origin, all over the world. A religious or spiritually motivated journey has become widespread and popularized in recent decades, occupying an important segment of international tourism (Olsen and Timothy, 2006).

Spiritual motives of the Vitovnica monastery were evaluated differently from cultural and historical motives in the survey. Although most of the respondents rated these 
motives with grade 5 , a significant number of respondents gave grades 3 and 4 . Seven respondents rated spiritual motives with grade 2 , while three respondents rated 1 . Spirituality in the modern world has a lot of challenges, especially with young people. The need to learn spiritual values in the modern world is very small. Considering that the younger population was predominantly involved in the survey, the results of spiritual motives were also expected. The presence of diversity of thinking about spiritual motives shows how many tourist motives need to be explored and, in accordance with the given results, implement measures for more effective and efficient growth and development of tourism in a particular destination (Chart 2).

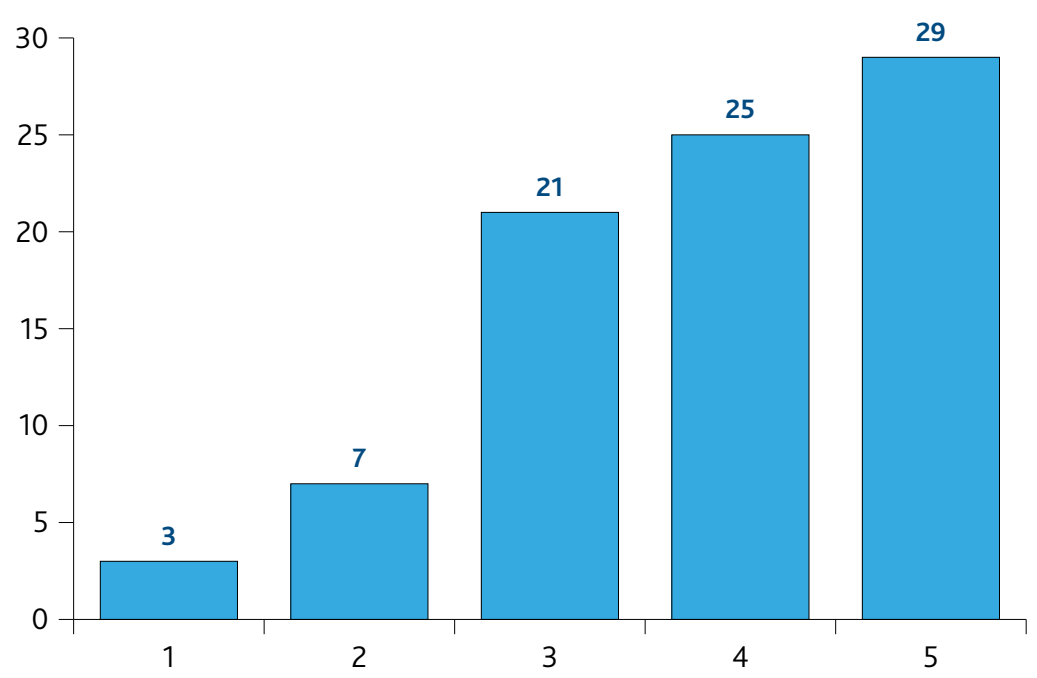

Chart 2. Evaluation of spiritual motives (number od respondents)

Artistic motives also predominate grade 5, and only one respondent rated it 1.A significant number of respondents rated these motives as grade 4 , while 16 respondents rated these motives as grade 3 .

Artistic motives in the monastery are most related to the iconographic work within the monastery church. However, one should mention the Vitovnica Gospel of the 16th century, which is beset with gold and silverVitovnica's glass. These works of art are not found in the Vitovnica Monastery, and this is a great disadvantage in terms of artistic tourist motives.

The art of the Monastery is also related to the architecture, the fresco of St. King Milutin, who was the founder of the monastery, and the Vitovnica's bowle for anaphora from the 17th century. These objects complement the tourist offer of the Monastery, and their preservation speaks of the monastic commitment to artistic values (Chart 3).

From the aspect of tourism affirmation, great attention should be focused on studying traditional values. They represent folklore heritage, that is, the foundations of material and spiritual culture. Important elements of folklore heritage include: costume, customs, way of life, homemade craftsmanship, original folk melos and traditional dishes (Paunović, 2001). Given that the Monastery possesses an exceptional historical identity, 


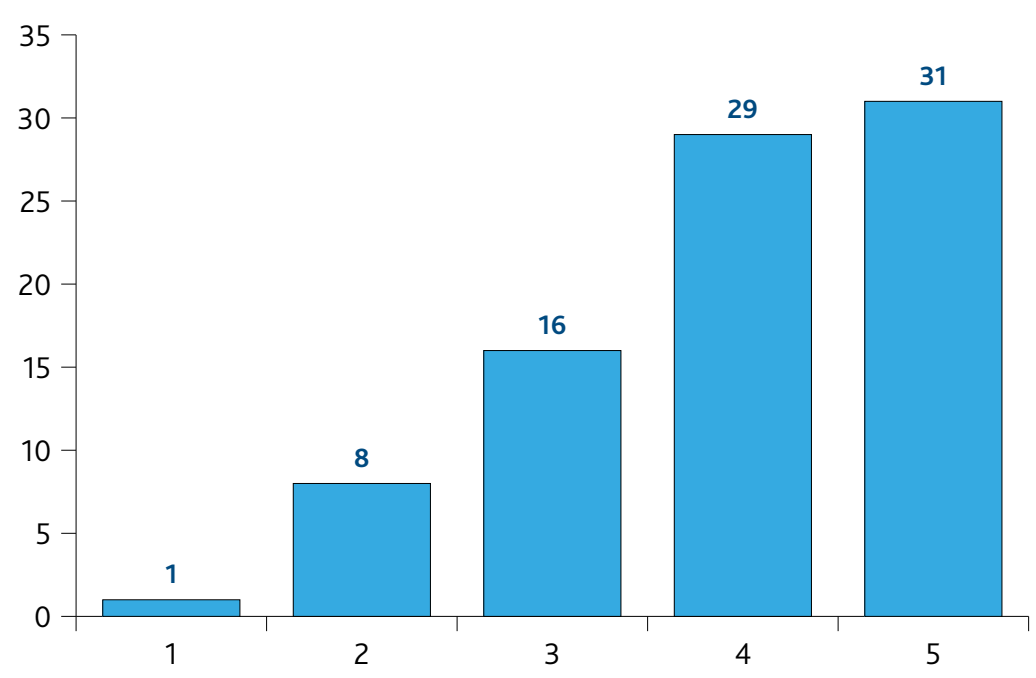

Chart 3. Evaluation of artistic motives (number od respondents)

it can be concluded that the motives of tradition and customs are an important part of the tourist offer. In addition, there is also an important complementary anthropogenic tourist value, which is a Vlach culture and tradition, which with its uniqueness definitely completes the tourist offer of the Monastery.

The motives of tradition and customs definitely dominated by grade 5 . Therefore, 54 respondents rated these motives with the highest grade. This indicates a very lively commitment to the traditional identity. Like many monasteries throughout the centuries, Vitovnica was a haven that took care of people, nurtured faith, and thus the tradition. None of the respondents rated the motives the lowest grade.The high score of these motives was potentially influenced by the complementary tourist offer, which is the Vlach

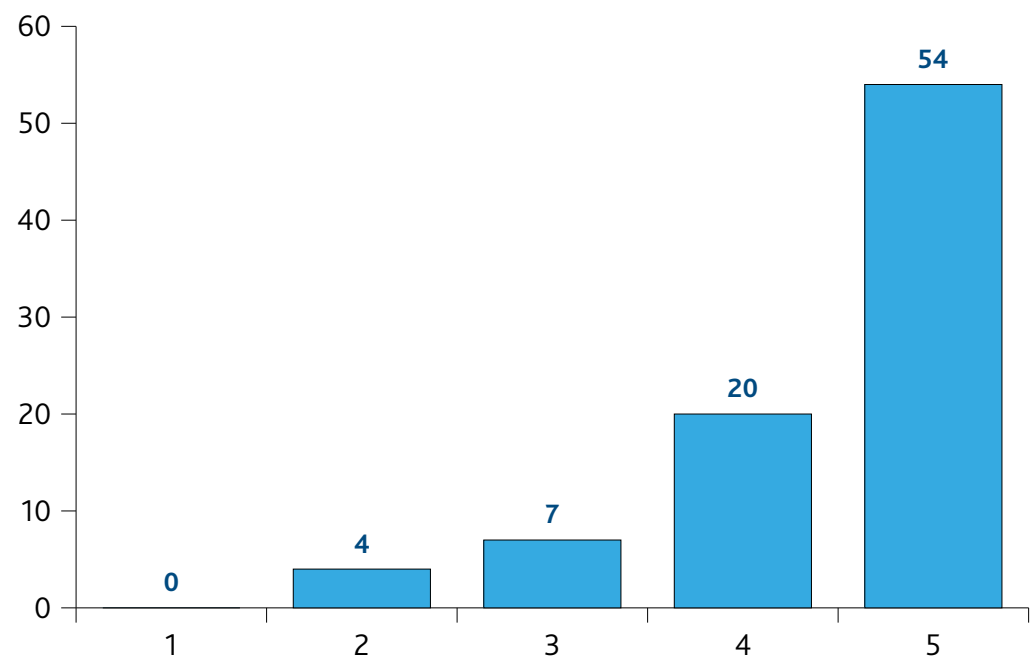

Chart 4. Evaluation of traditional motives (number od respondents) 
culture and tradition. Namely, Vlachs in their tradition have a great number of unique customs, which sometimes do not conform to Christian spiritual values. However, there were never any significant conflicts (Chart 4).

Scientific and educational tourism is one of the trends that have grown significantly in the last few years. Tourists begin to pay more attention to new ways to get acquainted with different tourist destinations, as well as learning opportunities. On certain occasions, learning activities at the destination are carried out in the form of a travel destination. This type of tourism is most often realized through school excursions and student trips. Many scientific disciplines, which previously depended on field expeditions, could not be developed without certain travel trips with an emphasis on scientific-educational motives (Benson, 2007).

As for the scientific-educational motives, opinions are divided the most. However, in this case, the majority of the respondents assessed the motives with grade 5 . What is surprising is that even 11 respondents rated the motives of the lowest grade, which means a negative figure.

Ratings 3 and 4 are medium-sized (between 5 and 25 respondents), while grade 2 gave 10 respondents. Negative assessment of scientific-educational motives indicates the absence of researchers among the respondents and the presence of very few potential tourists who had the opportunity to receive a certain level of knowledge about the Monastery through educational trips (Chart 5).

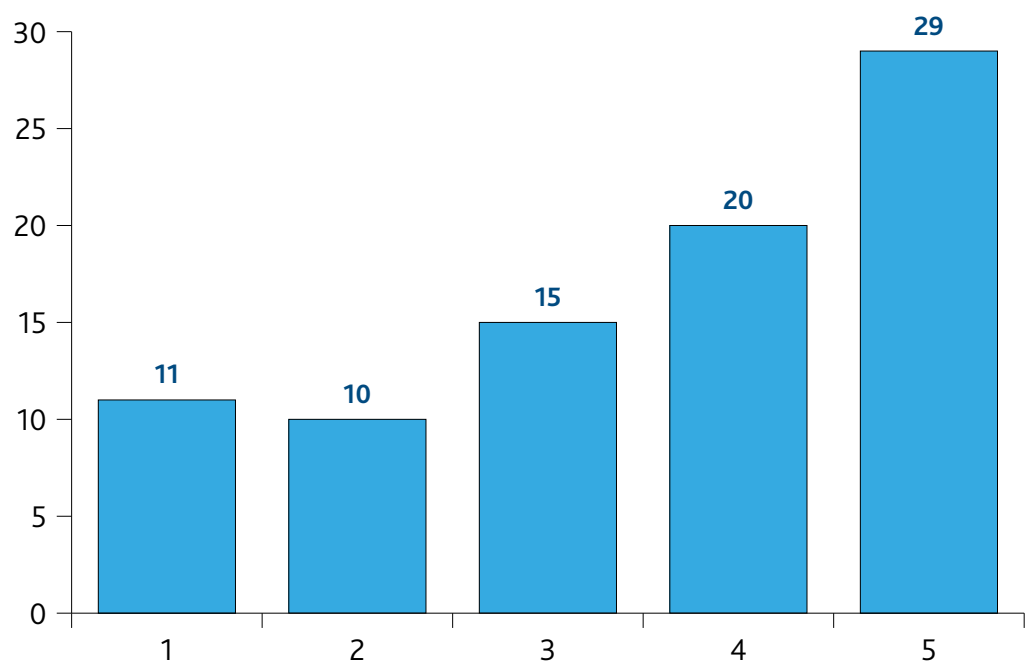

Chart 5. Evaluation of scientific-educational motives (number od respondents)

The calculation of the arithmetic mean in the paper presents the final estimate of all tourist motives. Chart 6 . contains the results of the final grades. It is noted that the motives of tradition and customs have the highest score of 4.4 ; in the second place there are cultural and historical motives with a score of 4.2, the artistic motives have a score of 3.9 , spiritual motives 3.8 , and the lowest average grade have scientific-educational motives with a score of 3.5 . 
Cultural-historical motives and motives of tradition and customs are the highest and as such, have the most important tourist potentials. It is surprising that the artistic motives are underestimated. There is a possibility that the absence of Vitovnica'sGlass, as well as the Vitovnica's Gospel, affects the weak assessment of artistic motives. Spiritual motives also have a weak estimate, which is the result of the dominance of the modern way of life, which is often incompatible with traditional spiritual values. Scientific-educational motives, as poorly rated, imply a low interest in scientific research and educational excursion visits to the Monastery (Chart 6).

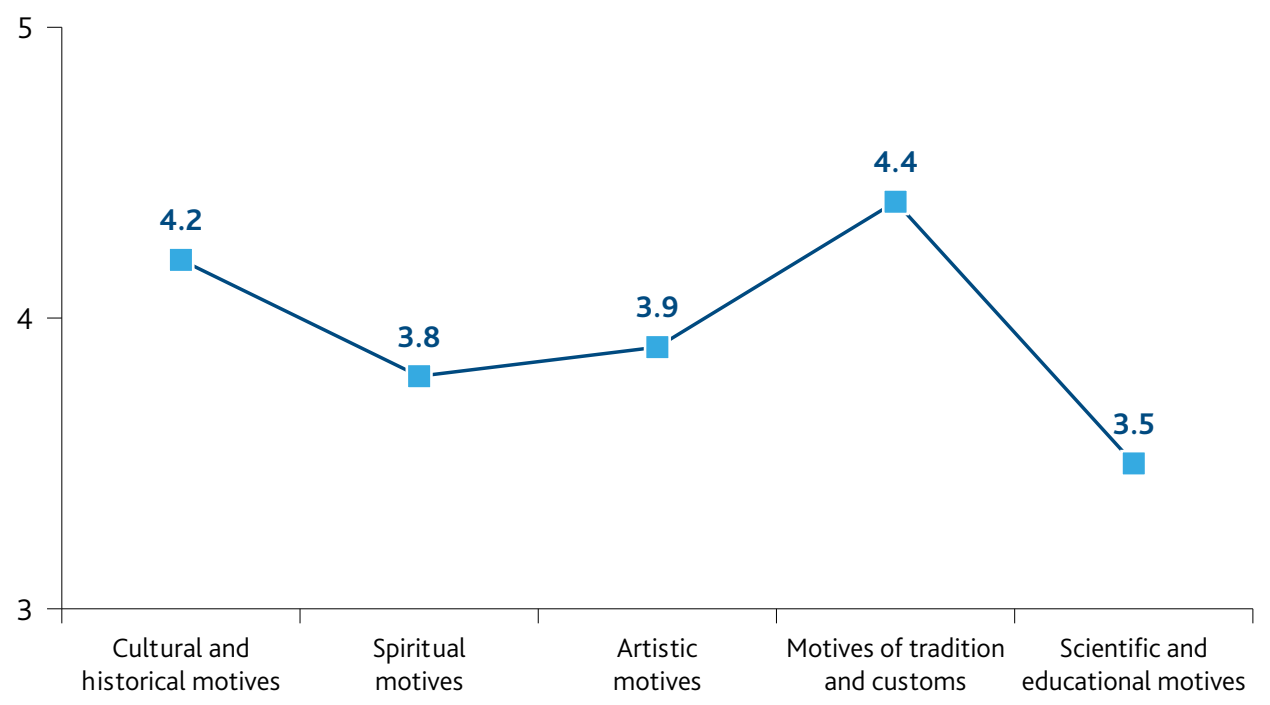

Chart 6. Average rating of tourist motives

In order to obtain the highest quality results, SWOT analysis was made. The strengths, weaknesses, opportunities and threats that the Vitovnica Monastery has in relation to the development of tourism are shown. From Table 2 we can conclude that the Monastery complex has significant advantages for the development of tourism, having in mind the favourable tourist-geographic space, rich anthropogenic basis, diverse natural environment and other tourist values. The disadvantages and threats faced by the Monastery when it comes to tourism are not unsolvable. This requires an expert team and good cooperation with the leadership of the Monastery and the Tourist Organization of Petrovac na Mlavi, since the Monastery is located on the territory of that municipality. Possibilities are numerous and promising. In addition to the fact that the Monastery has exceptional characteristics for the development of religious tourism and cultural tourism, it is possible to develop rural tourism with complementary offers of geoscientists and geotourism. The Vitovnica village, in which the Monastery is located, has many natural attractions such as: the Vitovnica River, the Mlava River, the hot water spring Ždrelo, the Ceremošnja cave, the Ravništarka cave, the Gornjak Gorge, etc. The realized survey showed that the most common motives of tradition and customs. According to the results of the SWOT analysis it is concluded that it is possible to im- 
plement complementary tourist offers, based on the natural environment in which the Monastery is located. In this way, tourists would get a better offer, which is based on tradition, culture and nature.

Table 2. SWOT analysis of Vitovnica monastery

\begin{tabular}{|c|c|}
\hline $\begin{array}{l}\text { STRENGTHS } \\
\text { 1. The monastery is located in the vicinity of } \\
\text { attractive natural tourist values (Gornjačka } \\
\text { gorge, Vitovnička river, Krupa spring, } \\
\text { Mreva spring, Ždrelo spa, Ceremošnja cave, } \\
\text { Ravništarka cave, etc.); } \\
\text { 2. The monastery complex has rich } \\
\text { anthropogenic tourist values; } \\
\text { 3. There is a rich ethnographic heritage; } \\
\text { 4. Unique architecture exists; } \\
\text { 5. Affordable tourist-geographical position; } \\
\text { 6. Well-preserved environment near the } \\
\text { monastery. }\end{array}$ & $\begin{array}{l}\text { WEAKNESSES } \\
\text { 1. Unavailable traffic infrastructure; } \\
\text { 2. Bad traffic signalization; } \\
\text { 3. Insufficient promotion; } \\
\text { 4. Indifference of tourists for spiritual motives; } \\
\text { 5. Insufficient involvement of the local } \\
\text { population in the tourism development of the } \\
\text { monastery; } \\
\text { 6. Insufficiently utilized natural resources; } \\
\text { 7. Great distance from accommodation } \\
\text { facilities. }\end{array}$ \\
\hline $\begin{array}{l}\text { OPPORTUNITIES } \\
\text { 1. Development of rural tourism as a chance of } \\
\text { Serbia and a trend on the global level; } \\
\text { 2. Development of religious tourism as a special } \\
\text { form of tourism; } \\
\text { 3. Connecting with other entities for a more } \\
\text { integrated tourist offer; } \\
\text { 4. Increased interest in getting to know the } \\
\text { village; } \\
\text { 5. Contribution to sustainable development and } \\
\text { environmental protection; } \\
\text { 6. Organizing manifestations in order to } \\
\text { maintain folklore and spiritual values; } \\
\text { 7. Increased focus on people staying in nature } \\
\text { and visiting historical sites; } \\
\text { 8. Possibility of staying in nature. }\end{array}$ & $\begin{array}{l}\text { THREATS } \\
\text { 1. Economic crisis; } \\
\text { 2. Unstable political environment; } \\
\text { 3. Frequent changes of executive power; } \\
\text { 4. Poor interest of the municipality for the } \\
\text { development of this type of tourism; } \\
\text { 5. Lack of support from republican authorities } \\
\text { for additional investments. }\end{array}$ \\
\hline
\end{tabular}

\section{CONCLUSION}

A large number of tourists travel with the goal of visiting cultural goods of a religious character.A religiously motivated journey is considered one of the oldest and most widespread reasons for traveling. There are many destinations that have become a nucleus of religious tourism and are attracting a large number of visitors every day. Events within sacred places and sacral buildings represent the oldest form of religious tourism (Gyekye, 2014).There are also tourists whose primary reason for the visit is not based solely on spiritual experience in the traditional sense. Such journeys are realized mostly because some cultural monuments are categorized as significant cultural heritage and 
represent cultural attractions worth visiting. Also, the reason for the visit can be the result of scientific and educational curiosity, a kind of complementary tourist offer or a way to get to know art and unique architecture. (Timothy and Boyd 2003).Within the monastery complex of Vitovnica monastery there are conditions for the development of cultural, religious and scientific-educational tourism. Considering this, we need to work intensively on the promotion of these tourist values and potentials.

Tourist valorisation, whether of cultural or natural potential, which includes some traditional aspects, has proven to be a key factor in the integration of history, culture and education. Many destinations of traditional character are visited by younger generations who, with an adequate tourist offer, can visit places where important historical events took place, to learn about their culture, past arts, historical figures and other factors related to the tradition and cultural identity of one place (Antić, et al. 2015).

Scientific-educational ambitions can contribute to the promotion of religious tourism, and educational motivations of tourists can be effective because they are considered as a factor through which tourists can expand not only their knowledge, but also their religious, cultural and environmental experiences (Ramírez \& Fernández, 2018). In this regard, the lowest rating of scientific-educative motives certainly negatively influences the development and promotion of the tourism of the monastery Vitovnica. It is necessary to realize more educational and scientific excursions, which can bring history and culture of the Monastery to the visitors.

The conducted research has shown significant aspects of the subjects and motives of the respondents regarding the anthropo-geographical and tourist offer within the monastery complex. The most common are the motives of tradition and customs, followed by cultural and historical motives, while the spiritual and scientific-educational motives are the least represented. This is supported by the fact that this Monastery is a very important cultural and historical monument, because it symbolically represents the final joining of Braničevo to the Serbian medieval state. Considering that the Monastery was built in the beginning of the 13th century and that it possesses an exceptional anthropogenic basis, it is concluded that its tourist potential is of great importance for the development of cultural and religious tourism in the Braničevo district, as well as other forms of tourism.

\section{REFERENCES}

Antić, A., Vujko, A. i Gajić, T. (2015). Tradicija kao pokretač razvoja turizma ruralnih destinacija. Škola biznisa, 2, 9-20.

Ambrož, M., \& Ovsenik, R. (2011). Tourist origin and spiritual motives. Management: journal of contemporary management issues, 16 (2), 71-86.

Benson, A. (2007). Research tourism. Niche Tourism, 133.

Bywater, M. (1994) Religious travel in Europe, Travel \& Tourism Analyst, 2: 39-52.

Dallen, T., Olsen, D. H. (ed.) (2006): Tourism, Religion and Spiritual Journeys. Barnes \& Noble. 
Dragović, M. (1933): Manastir Vitovnica. Separat časopisa "Braničevski zbornik". Požarevac.

Gyekye, A., Oseifuah, E., Nethengwe, T., Sumbana, F., \& Dafuleya, G. (2014). Religiously Motivated Travel and Rural Tourism in Vhembe District of South Africa. SHS Web of Conferences, 12, 1-9.

Hadžić, O. (2004). Neki aspekti saradnje u kulturnom turizmu. TURIZAM br. 8, 53.

Jackowski, A., \& Smith, V. L. (1992). Polish pilgrim-tourists. Annals of tourism research, 19(1), 92-106.

Mitošević, D. (1979). Manastir Vitovnica, zadužbina kralja Milutina, XIII vek. "D. Davidović". Smederevo.

Olsen, D. H., \& Timothy, D. J. (2006). Tourism and religious journeys. Tourism, religion and spiritual journeys, 1-21.

Paunović, B. (2001). Vlasi kroz vekove. Ćuprija: Mladost a.d.

Reisinger, Y. (2005). Leisure travel: National trends, cultural differences. Journal of Vacation Marketing, 11: 195-196.

Ramírez, R. R., \& Fernández, M. P. (2018). Religious Experiences of Travellers Visiting the Royal Monastery of Santa María de Guadalupe (Spain). Sustainability, 10(6), 1-19. Stojanović, LJ. (1926). Stari srpski zapisi i natpisi. Beograd.

Timothy, D.J. and Boyd, S.W. (2003). Heritage Tourism, Harlow: Prentice Hall. 